\title{
PREZENTACJE
}

Eleonora Sapia-Drewniak

Instytut Nauk Pedagogicznych

Zaktad Edukacji Ustawicznej

Uniwersytet Opolski

\section{Od wiejskiego nauczyciela do katedry uniwersyteckiej - droga awansu zawodowego Stanisława Gawlika}

Po odzyskaniu niepodległości przez państwo polskie w 1918 r. istotną rolę miał do spełnienia system oświaty. Silnie akcentowano konieczność demokratyzacji społeczeństwa poprzez edukację szkolną i pozaszkolną, zmierzano w ten sposób do stworzenia jedności kulturalnej narodu. Szczególnie zaniedbana była oświata na terenach wiejskich. Stosunki między szkołą wiejską a środowiskiem jej lokalizacji nie zawsze układały się poprawnie, bowiem ,szkoła traktowała wieś jako zacofaną i ciemną, zajęła wobec niej stanowisko niezależnej izolacji”". Jednak ta placówka oświatowa przygotowywała do życia poza wsią, dzięki czemu możliwy stawał się awans społeczny dzieci i młodzieży $\mathrm{z}$ tego środowiska.

W rozwoju i wychowaniu młodej generacji szczególną rolę przypisywano rodzinie wiejskiej, która wywierała wpływ na swoich członków nie tylko w okresie dzieciństwa, ale również w późniejszych latach, kiedy byli już w pełni dojrzałymi jednostkami. Ważne było nastawienie rodziców wiejskich do kształcenia dzieci, bo przecież musiało się ono odbywać kosztem ich bezpośredniego zaangażowania w pomoc w gospodarstwie rolnym. W rodzinach galicyjskich nauczycieli darzono szacunkiem, a wielu rodzicom bardzo zależało na wykształceniu wszystkich swoich dzieci.

Osobą, która dzięki zarówno wsparciu rodziny, jak i własnej pracy sukcesywnie osiągała kolejne szczeble w karierze zawodowej, zyskując zarazem coraz wyższą pozycję w hierarchii społecznej, jest Stanisław Gawlik, człowiek, który całe swoje dorosłe życie poświęcił nauczaniu młodzieży i ludzi dorosłych. Przebył on trudną drogę - od wiejskiego, początkującego nauczyciela, nieposiadającego przygotowania zawodowego do profesora uniwersyteckiego. Jego interesująca biografia nierozerwalnie związana z zawodową

1 S. Mauersberg, Komu stużyła szkoła w Drugiej Rzeczypospolitej? Społeczne uwarunkowania dostępu do oświaty, Wrocław-Warszawa 1988, s. 78. 
działalnością edukacyjną nie jest szerzej znana, dlatego też podjęłam się jej opracowania. Do jej przygotowania wykorzystałam głównie wywiady przeprowadzone na początku 2003 r. w ramach prowadzonych przeze mnie zajęć dydaktycznych ${ }^{2}$.

Pochodzący z wielodzietnej, rolniczej rodziny Stanisław urodził się na Podkarpaciu w Brzezinach w powiecie dębickim w 1928 r. W siódmym roku życia, tj. w 1935 r., zgodnie z obowiązującymi przepisami, rozpoczął w swojej miejscowości rodzinnej naukę w publicznej szkole powszechnej, dzięki dobrze przygotowanym nauczycielom poziom pracy dydaktyczno-wychowawczej był wysoki. W 1939 r. rozpoczęła się wojna, która nie przerwała działalności szkoły funkcjonującej przez wszystkie lata okupacji, w oparciu o przepisy władz niemieckich, zabraniające nauczania historii i geografii Polski oraz literatury ojczystej. Nauczyciele, chociaż pozornie posłuszni narzuconym rygorom, prowadzili działalność konspiracyjną, byli żołnierzami AK, zakładali nielegalne wypożyczalnie książek i organizowali na wsi tajne nauczanie. Od 1940 r. funkcjonowała m.in. w powiecie dębickim rozgałęziona grupa tajnego nauczania „Kuźnica”3. Wybuch wojny zakończył dla jedenastoletniego chłopca okres spokojnego dzieciństwa, a rozpoczął czas szybkiego dorastania.

Wykształcenie gimnazjalne zdobył na tajnych kompletach w Brzezinach. Nauczyciele dojeżdżali tam z różnych miejscowości. Szczególny nacisk kładziono na sprawy wychowawcze, starając się wzbudzać poczucie patriotyzmu wśród uczniów. Efekty ich pracy skutkowały m.in. tym, że Stanisław - podobnie jak jego koledzy szkolni - w wieku piętnastu lat, tj. w 1943 r. złożyli żołnierską przysięgę na wierność Ojczyźnie, stając się żołnierzem podziemia.

Po zakończeniu wojny Stanisław rozpoczął dalszą edukację 1 września 1945 r. w gimnazjum i liceum w Ropczycach. Zdał egzamin z zakresu programu realizowanego na tajnych kompletach i zaliczono mu trzy klasy gimnazjalne. Musiał zatem ukończyć tylko czwartą klasę. Po latach wspominał: Nauki było bardzo dużo. Należało nadrobić braki przede wszystkim z przedmiotów ścistych, powstałe $w$ okresie okupacji. Niezmiernie pomocni pod tym względem okazali się sami nauczyciele. Rozumieli oni młodzież i bardzo efektywnie z nia pracowali, częstokroć wieczorem, bezinteresownie, po godzinach lekcyjnych. A gdy zaistniała potrzeba udostepniali własne zbiory biblioteczne, pomagali $w$ interpretacji trudniejszych tekstów literatury pięknej4. Nauka w gimnazjum zakończyła się tzw. małą maturą, upoważniającą do kontynuowania edukacji w liceum. Pozostał w Ropczycach, gdzie w maju 1947 r. zdał egzamin dojrzałości. Ta placówka wywarła znaczący wpływ na ukształtowanie jego osobowości, głównie przez to, że grono pedagogiczne tworzone było przez współtwórców i realizatorów tajnego nauczania, uczestników walki podziemnej z najeźdźcą niemieckim, później sowieckim. Uzyskujący dobre wyniki w nauce Stanisław nie mógł jej kontynuować na uczelni wyższej, uniemożliwiała bowiem to

\footnotetext{
2 Pominięte zostały osiągnięcia naukowe S. Gawlika, wymagające pogłębionego, samodzielnego opracowania.

3 T. Wróblewska, Życie i twórczość profesora Kazimierza Kubika, w: Historia wychowania XX wieku. Dorobek i perspektywy, red. T. Gumuła, J. Krasuski, S. Majewski, Kielce 1998, s. 131.

${ }^{4}$ Na podstawie wywiadu przeprowadzonego ze Stanisławem Gawlikiem w 2003 r.
} 
trudna sytuacja materialna rodziny, w której młodsze rodzeństwo uczyło się w szkołach średnich. Musiał podjąć pracę zarobkową.

Bez większego przekonania zatem zdecydował się Stanisław na podjęcie pracy zawodowej w sektorze oświaty. W tamtym okresie na terenie całej Polski brakowało wykwalifikowanej kadry pedagogicznej. Zatrudnianie osób bez kwalifikacji było jedynym realnym do zastosowania rozwiązaniem5 ${ }^{5} 1$ września 1947 r. rozpoczął on pracę nauczycielską w Kamienicy Górnej, w powiecie jasielskim. Warunki lokalowe tej pierwszej placówki szkolnej były bardzo trudne. Drewniany budynek szkolny wzniesiony w początkach lat trzydziestych XX w. został poważnie uszkodzony podczas działań wojennych. Nie można było liczyć na pomoc ze strony mieszkańców wsi, gdyż sami byli bardzo biedni. Brakowało podstawowego wyposażenia szkoły, jakimi były ławki. Rodzice postarali się o ich przygotowanie, aby uczniowie mogli siedzieć podczas lekcji. Klasy liczyły nawet około 80 uczniów różniących się wiekiem, poziomem posiadanej wiedzy, stosunkiem do nauki. Wielu miało poważne braki edukacyjne, powstałe w czasie okupacji hitlerowskiej i działań frontowych. Mimo że część uczniów przekroczyła obowiązujący wiek szkolny, jednakże wykazywała zainteresowanie nauka, szanowała prace nauczyciela, wobec którego prezentowała postawy $w$ miare uprzejme, a w czasie zajęć lekcyjnych nie wymagała szczególniejszych upomnień dyscyplinujacych. Byty to dzieci i młodzież słabo odżywiona, źle odziana, a w zimie częstokroć nieprzychodzaca do szkoły ze względu na brak cieptej odzieży i niezbędnego obuwia ${ }^{6}$.

Podczas pracy w Kamienicy Górnej Stanisław Gawlik należał do tajnej organizacji Wolność i Niepodległość. W ramach jej działalności odbywały się w wybranych mieszkaniach tajne zebrania, na których omawiano kwestie sytuacji społecznej, politycznej i miejsca Polski w obozie państw socjalistycznych, a zarazem jej pozycji wobec ZSRR. Uczestnicy tych spotkań nie akceptowali narzuconego przez Sowietów porządku wewnętrznego kraju, tj. prześladowań opozycji, likwidacji indywidualnych gospodarstw chłopskich, niszczenia polskiej kultury. Wskazywano, że jest to nowa forma okupacji nie tylko terenu kraju, ale również polskiego ducha, z którego starano się usunąć chrześcijańskie tradycje. Podejmowano w ich trakcie dyskusje nad formami przeciwstawiania się wprowadzanemu porządkowi, zniechęcania ludności do aktywnego współdziałania z władzami. Niektórzy członkowie spośród nauczycieli uważali, że należy się przeciwstawić wprowadzaniu radzieckiego systemu politycznego i oświatowego w Polsce. Członkowie organizacji związani zawodowo z systemem edukacyjnym starali się interpretować program nauczania zgodnie z ideałem wychowania w okresie II Rzeczypospolitej.

W Kamienicy Górnej rozpoczęła się również działalność S. Gawlika w Związku Nauczycielstwa Polskiego. W Ognisku ZNP w Brzostku, do którego należała organizacyjnie szkoła, zetknął się z doświadczonymi nauczycielami, ludźmi dojrzałymi ideowo, ujawniającymi swój bunt wobec obcym polskiej tradycji oświatowej treściom nauczania oraz odgórnie narzuconym wartościom wychowania. Te początkowe doświadczenia, wynie-

${ }^{5}$ K. Terlecka, Liczba nauczycieli szkół podstawowych na Dolnym Śląsku w 30-leciu, w: Oświata na Dolnym Śląsu, pod red. A. Smołalskiego i F. Szafrańskiego, Warszawa 1980, s. 125.

${ }^{6}$ Na podstawie wywiadu przeprowadzonego ze Stanisławem Gawlikiem w 2002 r. 
sione z kontaktów z nauczycielami skupionymi w ognisku ZNP, miały istotny wpływ na ukształtowanie poglądów związanych z etosem zawodu nauczycielskiego młodego Stanisława. Wielu nauczycieli pod koniec lat czterdziestych poddano represjom za przynależność polityczną. Takiej sytuacji obawiał się S. Gawlik.

Po dwóch latach względnie spokojnej pracy w tej placówce w 1949 roku został on zmuszony do ucieczki i zmiany miejsca swego pobytu. Urząd Bezpieczeństwa wpadł bowiem na trop tajnej organizacji do której należał, dokonując licznych aresztowań w ostatniej dekadzie czerwca 1949 r., również wśród nauczycieli w Kamienicy Górnej. Szczęśliwym trafem uniknął on aresztowania, zamierzając bowiem podjąć studia wyższe, w tym czasie przebywał w Krakowie. O aresztowaniach dowiedział się od kolegi, wracając do wioski wczesnym rankiem. Ostrzeżono go, że w szkole czekają na niego funkcjonariusze Urzędu Bezpieczeństwa z Jasła. Od tamtego dnia nie nocował w swoim domu. Ukrywał się w różnych miejscach u życzliwych osób. Rozpatrując swoją sytuację, podjął decyzję o wyjeździe na Dolny Śląsk.

Rozpoczął się nowy etap w życiu Stanisława Gawlika. Syn jego kolegi był nauczycielem w szkole podstawowej na wsi w powiecie strzelińskim. On pomógł mu uzyskać zatrudnienie w szkolnictwie. Po przyjeździe, a właściwie ucieczce na Dolny Śląsk, Stanisław odkrył nad Odrą zupełnie inny świat ludzi, miast, wsi, komunikacji, sposobów organizacji oraz warunków pracy, znacząco różniący się od znanego mu z terenu Małopolski. W wyniku prowadzonej akcji osiedleńczej znalazły się tam grupy ludności z różnych stron kraju i Europy, różniące się między sobą bagażem doświadczeń, poziomem kulturalnym, cywilizacyjnym, zwyczajami. Nowe społeczności dążyły do tworzenia placówek szkolnych, by zaspokoić potrzebę edukacji dzieci. Nadzorowano więc przygotowywanie budynków szkolnych, mieszkań dla nauczycieli oraz kompletowano potrzebny sprzęt ${ }^{7}$. W ten sposób kształtowała się zarówno nowa społeczność dolnośląska, jak i tworzono od podstaw polskie szkolnictwo.

Władysław Kruczek, ówczesny inspektor szkolny w Strzelinie, do którego zgłosił się Gawlik, nie pytając o szczegóły życiowe młodego nauczyciela, skierował go do pracy w Szkole Podstawowej w Borku Strzelińskim. Inspektor przypuszczał, że pozostawał on w konflikcie z władzami bezpieczeństwa, dlatego też nie zaproponował mu pracy w miejscowościach, w których aktywnie działały komórki partyjne. Dokładnie pamiętam wspominał po latach S. Gawlik - spojrzat mi głęboko w oczy, nastepnie przenióst wzrok na mape powiatu i wskazał na kilka miejscowości, mówiąc głośno, jakby tylko do siebie: [...] tu Pana nie powinienem skierować, tam też nie, ale mam takiego doskonatego kierownika szkoły w miejscowości Borek Strzeliński, który się Panem należycie zaopiekuje. I tam też się udałem $^{8}$. Miało to miejsce 31 sierpnia $1949 \mathrm{r}$.

Region ten był całkowicie nieznany młodemu nauczycielowi, ale szybko stał się mu niezwykle bliski. Z upływem lat wielki sentyment do Śląska, nieustannie się pogłębiał.

\footnotetext{
${ }^{7}$ M. Lazarska, Rola nauczycieli $w$ tworzeniu dolnośląskiej oświaty w okresie pionierskim w świetle wspomnień, w: Oświata na Dolnym Śląsku. Organizacja i kierunki działalności dydaktyczno-wychowawczej, pod red. B. Potyrały, Wrocław 1987, s. 142 i n.

${ }^{8}$ Na podstawie wywiadu przeprowadzonego ze Stanisławem Gawlikiem w 2002 r.
} 
Od tamtego czasu ponad 60 lat swego życia związał najpierw z Dolnym Śląskiem, a później z Opolszczyzną. Podejmując pracę dydaktyczną posiadał uzasadnione obawy, czy długo będzie mógł przebywać na wolności. Konsekwencją tego była podejrzliwość wobec ludzi, szczególnie tych pojawiających się w jego otoczeniu niespodziewanie, w mało przekonywającej sprawie, a wykazujących nieuzasadnione zainteresowanie jego osobą.

Szkołą w Borku kierował doświadczony nauczyciel, któremu Stanisław zawdzięcza wiele wartościowych i fachowych wskazówek niezbędnych w pracy dydaktycznej, będących następnie podstawą do budowania własnego warsztatu zawodowego. Od pierwszego dnia musiał sobie przyswoić, że pierwszoplanowym obowiązkiem nauczyciela jest praca z dziećmi, a więc realizowanie procesu edukacyjnego. W placówce tej uczył języka polskiego, biologii oraz geografii w klasach od V do VII. Były to trudne obowiązki, nie czuł się w tym zakresie kompetentny ani metodycznie, ani merytorycznie. Kiedy podzielił się swoimi wątpliwościami z kierownikiem, pomoc w zakresie przygotowywania konspektów lekcyjnych, interpretowania programów szkolnych, i w doborze celów nauczania, zaoferowała jego żona. Ona wskazywała mu literaturę metodyczną, pedagogiczną wydaną przed 1939 r. ${ }^{9}$ S. Gawlik wracając po latach do tamtych czasów wspominał: niewiele wartościowych pozycji stużacych doskonaleniu zawodowemu nauczyciela ukazało się w latach tuz powojennych, a od 1948 roku zaczęła się nieustępliwa indoktrynacja szkoły przez partyjno-rzadowa propagande prosowiecka. To smutne, ale stracono wtedy, nie z własnej woli, odwagę publikowania nie tylko dzieł pedagogicznych, ale również psychologicznych i socjologicznych autorów polskich, a urzędowo zalecono tylko literature sowieck ${ }^{10}$.

Wszyscy nauczyciele Szkoły Podstawowej w Borku Strzelińskim z niepokojem śledzili niekorzystne przemiany społeczne-polityczne, czego wyrazem był narastający brak zaufania do nauczyciela ze strony czynników politycznych. Środowisko nauczycielskie było nieufne wobec nowych poczynań władz oświatowych. Związane to było z rozbieżnością między tym, co oficjalnie głosił resort oświaty, a postępowaniem władz administracyjnych i politycznych $\mathrm{w}$ regionie ${ }^{11}$.

Ze szczególną ostrością atakowano te szkoły, w których nie działała Polska Zjednoczona Partia Robotnicza. A tak właśnie było w Borku Strzelińskim, gdzie zarówno kierownik jak i grono nauczycielskie należeli do Polskiego Stronnictwa Ludowego. Instrukcja programowa na rok szkolny 1949/1950 zobowiązywała nauczycieli do nasycenia treści wszystkich przedmiotów elementami ideologicznymi, co miało spowodować wzrost poziomu wyrobienia politycznego uczniów, kształtować ich światopogląd i zaangażowanie w budownictwo socjalizmu. Wymienione założenia - jak napisano w instrukcji ,zamykały okres walki z pozostałościami sanacyjnego programu w naszej szkole"12.

\footnotetext{
${ }_{9}$ Na podstawie wywiadu przeprowadzonego ze Stanisławem Gawlikiem w 2003 r.

${ }^{10}$ Ibidem.

11 B. Potyrała, Środowisko nauczycielskie w Polsce po 1944 roku, w: Nauczyciele w procesie przemian oświatowych, pod red. B. Potyrały, Wrocław 1992, s. 76-79.

12 Dziennik Urzędowy Ministerstwa Oświaty 1949, nr 12, poz. 200. Instrukcja programowa na rok szkolny 1949/1950 w szkolnictwie ogólnokształcącym.
} 
Od tego czasu nauczyciele mieli obowiązek szkolenia ideologicznego prowadzonego w ramach rad pedagogicznych, na konferencjach organizacji związkowej, odprawach kierowników i dyrektorów szkół oraz przedszkoli, a także na specjalnych kilkudniowych kursach organizowanych przez ZNP, który pod tym względem był uzależniony od PZPR. I chociaż nauczyciele nie garnęli się do udziału w tego rodzaju zajęciach, to jednak traktując je jako zło konieczne, jako wymóg pozostania w zawodzie, uczestniczyli w nich, częstokroć biernie.

Młody Stanisław w tym okresie uczył języka polskiego. Doświadczył zdumiewającej sytuacji na lekcji, którą tak opisywał: Dzisiaj może to zostać uznane za rzecz śmieszna, ale takie zdarzenie rzeczywiście zaistniało. Pewien urzędnik partyjny szczebla powiatowego w Strzelinie, obecny na mojej lekcji języka polskiego w klasie V, której tematem było stopniowanie przymiotników, gdy uczniowie stopniujac przymiotnik dobry wymienili poprawnie: dobry - stopień równy, lepszy - stopień wyższy, najlepszy - stopień najwyższy, pojawit się przed uczniami i bezceremonialnie oświadczyl, że źle nauczam. Jako, że ta oczywista prawda nie była zgodna z jego ideologiczno-proletariacka myśla, ku nie tylko mojemu ogromnemu zdumieniu sam oznajmił uczniom, nie zważajac na obecność kierownika szkoły $i$ wizytatora, którzy niemal ostupieli, ̇̇e stopień najwyższy przymiotnika dobry winien brzmieć - radziecki. I kto obecnie jest zdolny uwierzyć, że tak serdecznie i przyjaźnie brzmiacy wyraz, zapowiadajacy coś dobrego, spowoduje coś odwrotnego, bo przypisanie mi postawy antyradzieckiej. To, co wtedy zaszło, na dtuższy czas stało się przedmiotem niewybrednych żartów pod adresem działaczy partyjnych ${ }^{13}$.

W trakcie pracy w Borku Strzelińskim Stanisław Gawlik wielokrotnie uczestniczył w konferencjach rejonowych organizowanych przez ZNP, mających na celu doskonalenie zawodowe nauczycieli. Odbywały się one raz w miesiącu, kiedy nauczyciele ustawowo korzystali z dnia wolnego. Miały przygotować pedagogów nieposiadających odpowiednich kwalifikacji do wykonywania tego zawodu - a takim był Stanisław. Na każdej była przeprowadzona lekcja pokazowa, którą następnie omawiano pod kątem metodycznym oraz referat teoretyczny, wygłaszany zazwyczaj przez nauczyciela mającego profesjonalne przygotowanie merytoryczne i praktyczne doświadczenie dydaktyczne. Na tychże konferencjach rejonowych wiele się S. Gawlik nauczył, co pozwoliło mu dokształcić się oraz doskonalić własne kompetencje nauczycielskie. Sam przeprowadził kilka lekcji pokazowych, co wymagało od niego dużego nakładu pracy, jak i poddaniu się ocenie związanej z jej przebiegiem. Każdy szczegół omawiano krytycznie, lecz zarazem konkretnie i życzliwie. Dzięki tym konferencjom rejonowym nauczył się organizacji pracy dydaktycznej. Przypominam sobie, kiedy swego czasu taka lekcję pokazowa prowadziłem, zdaje się pierwsza, przedtużylem czas poza 45 minut, to wszyscy jej uczestnicy $w$ czasie dyskusji nad nią byli zgodni, że po 45 minutach jest czas przeznaczony dla ucznia, oni maja prawo wyjść wtedy z lekcji, bo nauczyciel, a w tym przypadku ja, zabiera im własny $c z a s^{14}$. Ta sytuacja wymuszała na zespole pedagogicznym konieczność samokształcenia, jeśli zamierzano osiągać pozytywne rezultaty w pracy z uczniami. Po części oficjalnej

\footnotetext{
13 Na podstawie wywiadu przeprowadzonego ze Stanisławem Gawlikiem w 2003 r.

${ }^{14}$ Na podstawie wywiadu przeprowadzonego ze Stanisławem Gawlikiem w 2002 r.
} 
konferencji organizowana była część towarzyska, pozwalająca nauczycielom na lepsze wzajemne poznanie się, wymianę poglądów związanych z pracą zawodową, życiem prywatnym, dzięki czemu tworzyli oni grupę ludzi współpracujących ze sobą nie tylko na terenie szkoły, ale również w lokalnym środowisku.

Jako niewykwalifikowany nauczyciel w celu doskonalenia swoich umiejętności dydaktycznych Gawlik w lipcu 1950 r. uczestniczył w wykładach prowadzonych w Liceum Pedagogicznym we Wrocławiu przy ulicy Dawida 1. Tam złożył egzamin z zakresu programu nauczania obowiązującego w liceum pedagogicznym, dający kwalifikacje do nauczania w szkolnictwie podstawowym. Po ich uzyskaniu 1 października tego roku zmienił miejsce pracy. Przeniósł się do kolejnej dolnośląskiej wioski - Ludowa, gdzie pracował przez dwa lata, tj. do 1952 r. W drugim roku nauczania w tej miejscowości, a po czterech latach pracy zawodowej, we wrześniu 1951 r. został dyrektorem siedmioklasowej szkoły z klasami łączonymi, w której zatrudnionych było trzech nauczycieli.

Mieszkająca tutaj ludność z Kresów Wschodnich, zwłaszcza Wołynia w znacznym stopniu była analfabetami. Dla nich, podobnie jak wcześniej w Borku Strzelińskim, organizowano kursy nauczania początkowego. Wtedy miał miejsce pierwszy kontakt S. Gawlika z dorosłym uczniem. Zapamiętał on widok zawstydzonych matek, które w ramach ogólnopolskiej, przymusowej akcji walki z analfabetyzmem zasiadały wieczorem w tych samych ławkach, w których w ciągu dnia siedziały ich dzieci. Mężczyźni bardziej lekceważąco podchodzili do tego obowiązku, często na zajęcia lekcyjne przynosząc alkohol.

Zaangażowanie w pracę dydaktyczną w wiejskich szkółkach spowodowało, że dwukrotnie kuratorium dolnośląskie proponowało Stanisławowi Gawlikowi przejście do pracy w nadzorze pedagogicznym na stanowisko zastępcy inspektora szkolnego w Strzelinie. Nie skorzystał jednak z tej oferty. Jako osoba poszukiwana od 1949 r. obawiał się, że prawdopodobieństwo jego aresztowania w czasie nasilonych represji aparatu bezpieczeństwa jest bardzo duże. Stąd bezpieczniej było pracować w środowisku wiejskim.

Wykazywał S. Gawlik niechętny stosunek do zawiązania w Ludowie Śląskim spółdzielni produkcyjnej, której utworzenie miało stanowić podwaliny nowego, socjalistycznego porządku społeczno-gospodarczego w środowisku wiejskim, dotychczas - jak wmawiano chłopom - pogrążonego w nieświadomości klasowej. Stanowisko takie niepokoiło tych, którzy mieli decydujący wpływ na losy gospodarcze wsi. Na 26 października 1952 r. wyznaczono wybory do Sejmu. Towarzyszyła im nasilona propaganda i zastraszanie społeczeństwa, ale również eliminowanie osób niepewnych politycznie, co spowodowało zwiększone aresztowania dokonywane przez Ministerstwo Bezpieczeństwa Publicznego. Obawiano się, że również S. Gawlik nie będzie zachowywał się lojalnie wobec władzy politycznej, dlatego zamierzano go wyeliminować z życia publicznego.

Dnia 27 września 1952 r. doszło do jego aresztowania w godzinach porannych na terenie szkoły ludowskiej, na oczach zdezorientowanych uczniów i nauczycieli. Znalazł się we wrocławskim więzieniu przy ulicy Kleczkowskiej, gdzie przetrzymywano go poddając codziennym przesłuchaniom, a następnie przewieziono do Rzeszowskiego Urzędu Bezpieczeństwa. Był tam sądzony przez Rejonowy Sąd Wojskowy i 7 stycznia 1953 r. 
skazany na 6 lat pozbawienia wolności, przepadek mienia oraz utratę praw obywatelskich i honorowych na lat 5 za działalność na szkodę państwa ludowego. W części końcowej wyroku, sąd opowiedział się również za pozbawieniem go praw do wykonywania zawodu nauczycielskiego. Karę odbywał w miejscowości Piechcin koło Potulic w dawnym woj. bydgoskim, gdzie więźniowie pracowali w odkrywkowej kopalni kamienia wapiennego w Bielawie. Konsekwencją tej pracy były choroby dróg oddechowych, dolegliwości dermatologiczne, ropne zapalenie gardła, które nieleczone w trakcie odbywania kary, spowodowało konieczność operacji po opuszczeniu zakładu karnego.

$\mathrm{Na}$ mocy amnestii wyrok S. Gawlika uległ złagodzeniu o jedną trzecią. W wyniku postanowienia Wojskowego Sądu Rejonowego w Krakowie z dnia 10 listopada 1954 r. został warunkowo zwolniony z dalszego odbywania kary. Zakład karny opuścił 13 listopada 1954 r. Był zobowiązany do meldowania się co dwa tygodnie w najbliższej miejsca zamieszkania komendzie Milicji Obywatelskiej i każdorazowym zawiadamianiu sądu o zmianie czasowego miejsca pobytu.

Wrócił na Dolny Śląsk do Ludowa z nadzieją, że znajdzie tu możliwość dalszego wykonywania zawodu nauczycielskiego. Nie udało się to jednak. Bardzo ciepło przyjęli go jedynie mieszkańcy wsi, niestety, nie starał się nawiązać z nim żadnego kontaktu następca na stanowisku kierownika szkoły w Ludowie Śląskim. Przeciwnie, ostrzegał dzieci i ich rodziców przed osobistym z nim kontaktem jako człowiekiem niepewnym politycznie. Stroniły też od niego nauczycielki, z którymi w przeszłości pracował. Jedynie wypróbowani przyjaciele zadeklarowali pomoc w znalezieniu dla niego pracy. Ówczesny kierownik Wydziału Oświaty Powiatowej Rady Narodowej we Wrocławiu wiedząc, że S. Gawlik pozbawiony jest uprawnień do nauczania, mimo wszystko narażając siebie, podjął decyzję o zatrudnieniu go w charakterze nauczyciela w Szkole Podstawowej w Mnichowicach, wsi położonej $16 \mathrm{~km}$ na południe od Wrocławia.

Osoby życzliwe nauczycielowi przekazały mu informację, że środowiskowi działacze partyjni nadmiernie interesują się jego przeszłością. W obawie o własne bezpieczeństwo rozwiązał zatem stosunek służbowy w kuratorium dolnośląskim i przeniósł się w $1956 \mathrm{r}$. do Brzegu w województwie opolskim. Tam powierzono mu kierownictwo Szkoły Podstawowej dla Pracujących w Lewinie Brzeskim. Chociaż bez uprawnień, Gawlik był wtedy również kierownikiem Szkoły Podstawowej w Skarbimierzu, wsi graniczącej z Brzegiem. Tam wspólnie z żoną (w lipcu 1956 r. ożenił się z Marią Grzesiowską) pracowali przez dwa lata, ucząc dzieci w klasach I-V. W styczniu 1957 r. przywrócono mu prawo do wykonywania zawodu nauczycielskiego. Od 1 września 1959 r. Maria i Stanisław Gawlikowie przenieśli się do szkoły siedmioklasowej w Czeskiej Wsi, niedaleko Brzegu.

Równolegle z pracą zawodową S. Gawlik podjął studia w trybie zaocznym, początkowo na kierunku historii w Wyższej Szkole Pedagogicznej w Krakowie - od 1957 r., a następnie na kierunku pedagogika w Wyższej Szkole Pedagogicznej w Opolu, gdzie uzyskał magisterium z pedagogiki. Przygotował pracę magisterską pt. „Szkolnictwo podstawowe na Ziemi Brzeskiej 1945-1965”, pod kierunkiem znanego historyka oświaty i wychowania prof. Józefa Madei.

W tym czasie S. Gawlik był kierownikiem Sekcji Historii Powiatowego Ośrodka Metodycznego w Brzegu. Aktywnie działał jako członek prezydium w Oddziale Powia- 
towym Związku Nauczycielstwa Polskiego, gdzie sprawował funkcję kierownika Wydziału Pedagogicznego, odpowiadającego za doskonalenie zawodowe nauczycieli. Przez kilka kadencji wchodził też w skład Zarządu Okręgu ZNP w Opolu.

W roku 1966 - po ukończeniu studiów wyższych - zamieszkał wraz z rodziną w Brzegu, gdzie został powołany na stanowisko dyrektora Liceum Ogólnokształcącego dla Pracujących ${ }^{15}$. Podobnie jak we wcześniejszych placówkach, wykazywał dużą aktywność organizacyjną, która sprawiła, że w krótkim czasie powstały trzy filie tegoż liceum: w Namysłowie, Grodkowie i Lewinie Brzeskim. Biorąc pod uwagę fakt, że wielu pracowników różnych urzędów publicznych, zwłaszcza w mniejszych miastach i wojska nie posiadało wtedy ukończonej szkoły średniej, wieczorowa forma organizacyjna nauki stanowiła dla nich jedyną szansę osiągnięcia wykształcenia na tym poziomie. Funkcję dyrektora tej szkoły średniej pełnił do 1978 r., kiedy przeszedł do pracy w Opolu w Instytucie Kształcenia Nauczycieli. Tam powierzono mu funkcję kierownika Zakładu Doskonalenia Kadr Kierowniczych w Oświacie ${ }^{16}$.

S. Gawlik podnosił swoje kwalifikacje ogólne i zawodowe, zdając sobie sprawę, że może to uchronić go przed degradacją zawodową, dla czynników partyjnych bowiem ciągle był osobą niepewną politycznie. Nawiązał kontakt z profesorem Teodorem Musiołem dyrektorem Instytutu Pedagogiki w Wyższej Szkole Pedagogicznej w Opolu. W tej uczelni, w 1974 r. na podstawie rozprawy ,Szkolnictwo podstawowe dla pracujących na Opolszczyźnie w latach 1945-1970” przygotowanej pod jego kierunkiem, uzyskał Stanisław Gawlik stopień doktora nauk humanistycznych.

Rok 1981 to początek jego pracy w Wyższej Szkole Pedagogicznej w Opolu w Instytucie Pedagogiki. Wtedy zmieniły się warunki społeczno-polityczne wywołane ruchem solidarnościowym. Już wcześniej dr Gawlik podejmował starania o zatrudnienie w uczelni opolskiej. Były one jednak bezskuteczne, władze partyjne bowiem kategorycznie nie zgadzały się na to - wciąż był dla nich człowiekiem politycznie niepewnym. Sekretarz do spraw propagandy KW PZPR oświadczył, że na uczelni wyższej nie będziecie mogli u nas pracować. Ja i towarzysze ze Stużby Bezpieczeństwa na to nie pozwolimy ${ }^{17}$. Stało się jednak inaczej. W październiku 1981 r. został zatrudniony na stanowisku adiunkta w WSP w Opolu, a parę miesięcy później przeprowadzono przewód habilitacyjny w WSP w Krakowie. Podstawą była monografia pt. „Dzieje kształcenia nauczycieli na Śląsku Opolskim". W styczniu 1983 r. awansował na stanowisko docenta. Po dziesięciu latach, tj. w 1993 r. otrzymał tytuł naukowy profesora nauk humanistycznych ${ }^{18}$.

Awans naukowy sprawił, że zwiększał się zakres jego obowiązków uczelnianych. W 1984 r. został zastępcą dyrektora ds. naukowych w Instytucie Pedagogiki. Tę funkcję

\footnotetext{
15 Do 31 sierpnia 1966 r. w Brzegu mieściła się filia Liceum Ogólnokształcącego dla Pracujących w Opolu, którym kierowała mgr Maria Piwońska, historyczka z wykształcenia. Od 1 września 1966 r. dotychczasowa filia stała się samodzielną szkołą, z siedzibą w Liceum Ogólnokształcącym im. Bolesława Chrobrego, ul. Armii Krajowej (dawnej J. Marchlewskiego).

16 Archiwum Uniwersytetu Opolskiego, teczka osobowa prof. S. Gawlika.

17 Na podstawie wywiadu przeprowadzonego ze Stanisławem Gawlikiem w 2003 r.

${ }_{18}$ Oświata: tradycje $i$ współczesność. Praca ofiarowana Profesorowi dr. hab. Stanisławowi Gawlikowi w siedemdziesiąta rocznicę urodzin, pod red. J. Kwiatek i F.A. Marka, Opole 1999, s. 7-8.
} 
sprawował do 1989 r. Został wtedy prodziekanem Wydziału Filologiczno-Historycznego, a następnie dziekanem tegoż. W ramach struktury organizacyjnej Instytutu Nauk Pedagogicznych Uniwersytetu Opolskiego S. Gawlik był kierownikiem Zakładu Pedagogiki Ogólnej, przekształconej w Zakład Pedagogiki Opiekuńczo-Wychowawczej, a w 1992 r. w Katedrę Badań nad Szkołą. W latach 1996-1999 był dziekanem nowo utworzonego Wydziału Historyczno-Pedagogicznego. Funkcję tę sprawował przez jedną kadencję, czyli do końca roku akademickiego 1998/99, kiedy osiągnął wiek emerytalny i przeszedł w stan spoczynku.

Profesor Stanisław Gawlik był osobą niezwykle zaangażowaną w pracę nauczycielską zarówno z dziećmi, młodzieżą, jak i przede wszystkim z dorosłymi. Od lat 70. ubiegłego wieku łączył ją z pracą naukową. Fascynowała go historia oświaty i wychowania zarówno w wymiarze regionalnym, jak i ogólnopolskim, której poświęcił swoje poszukiwania badawcze. Wywodząc się ze skromnej rodziny wiejskiej, nauczył się pokonywać trudności życia w skomplikowanych układach społeczno-politycznych ówczesnej Polski oraz nie poddawał się przeciwnościom losu. Przeszedł wszystkie szczeble kariery zawodowej - od nauczyciela podkarpackiej, wiejskiej szkółki, poprzez kierownika dolnośląskiej szkoły wiejskiej, dyrektora liceum dla dorosłych, po profesora uniwersyteckiego. Jego życie to nieustanna edukacja zarówno w wymiarze formalnym, jak i czerpana z codzienności. Mimo że w zawodzie nauczycielskim znalazł się przypadkowo, dzięki namowie starszego kolegi, to przez własną aktywność, wytrwałość i kreatywność stał się w pełni wartościowym pedagogiem. 